Losing an Empire, Finding a Role 
Also by David Sanders

Patterns of Political Instability

Lawmaking and Co-operation in International

Politics: The Idealist Case Re-examined 


\title{
Losing an Empire, Finding a Role
}

An Introduction to British Foreign Policy since 1945

\author{
David Sanders
}

Macmillan Education 
ISBN 978-0-333-44266-1 ISBN 978-1-349-20747-3 (eBook)

DOI 10.1007/978-1-349-20747-3

(C) David Sanders. 1989

Softcover reprint of the hardcover 1st edition 1989

All rights reserved. For information, write:

Scholarly and Reference Division,

St. Martin's Press, Inc., 175 Fifth Avenue,

New York, N.Y. 10010

First published in the United States of America in 1990

ISBN 978-0-312-04150-2

Library of Congress Cataloging-in-Publication Data

Sanders, David, 1950-

Losing an empire, finding role.

Includes bibliographical references.

1. Decolonization-Great Britain-History-20th

century. 2. Great Britain-Foreign relations-

1945- . 3. Great Britain-Colonies-History-20th

century. I. Title.

DA589.8.S26 $1989 \quad 327.41^{\prime} 009^{\prime} 04 \quad 89-29484$

ISBN 978-0-312-04150-2 
FOR

GILL, JOE, BEN, ROB AND LUCY 


\section{Contents}

Preface $\quad$ ix

Introduction 1

1 Before $1945 \quad 17$

Before $1914 \quad 17$

The interwar years: Realism versus Idealism 21

The impact of the Second World War $\quad 32$

Summary and conclusions $\quad 43$

2 From Potsdam to Cold War: Relations with Europe and the Superpowers, 1945-55

Britain's international position in 1945

Decline and recovery: the transformation in Anglo-American strategic relations, 1945-8 52

The consequences of Anglo-American interest convergence, 1946-55

Summary and conclusions

3 The Road to Suez: British Imperialism, 1945-56 74

Withdrawal: India and Palestine 75

Retrenchment: Malaya, the Caribbean and Africa 82

Retrenchment and withdrawal: Suez $\quad 88$

Summary and conclusions $\quad 96$

4 The Wind of Change: The Empire Circle after $1956 \quad 100$

$\begin{array}{ll}\text { The effects of Suez } & 101\end{array}$

The 'second wave' decolonisations: Africa and the
Caribbean after 1956

The withdrawal from east of Suez $\quad 112$

After 1968: imperialism without colonies? $\quad 120$

Summary and conclusions $\quad 131$

5 The Search for a New Role: The European Circle after 1956135

Increasing involvement in the European circle, 1956-72 136

Explaining the shift towards Europe 143

Britain's relations with Europe after $1972 \quad 156$

Summary and conclusions 166 
6 The Changing 'Special Relationship', 1956-88 169

Developments in Anglo-American relations, 1956-88 170

Continuity and change in Anglo-American relations: some explanatory factors

Summary and conclusions

7 The International Economic Dimension

The attempt to preserve a dominant world financial role, 1945-68

The shift to a more reactive strategy, 1968-88 210

Summary and conclusions

8 Defence Policy

Defence policy in the Empire circle, 1945-88

Defence policy in the European and Atlantic circles: NATO

Summary and conclusions

9 The Relevance of Foreign Policy 'Theory' 257

Realist world-views and the Realist model 258

The contribution of other theoretical approaches $\quad 272$

Summary and conclusions $\quad 285$

10 Conclusions 288

The problem of overextension 288

Postscript: Britain's international role 290

Appendix: Treaties and Agreements entered into by the UK Government, January-December 1967295

Notes and References 298

Bibliography $\quad 326$

Author Index $\quad 338$

Subject Index 341 


\section{Preface}

This book grew out of a series of lectures that I first gave at the University of Essex during the academic session 1985-6. The lectures posed two main questions. What have Britain's major foreign policies been during the postwar period? And why were those policies pursued? What surprised me as I prepared the lectures was the extent to which existing studies of British foreign policy - excellent though many of them are - failed to address either question directly. While recognising the difficulty of answering either question definitively, this book does seek to answer them both. For presentational purposes, I make two assumptions: that 'foreign policy' refers to all aspects (political, military and economic) of a given country's external relations; and that the reader is intelligent but is largely uninformed of the details of Britain's postwar foreign policy.

In writing the book I benefited enormously from the advice offered by colleagues at Essex and elsewhere. I am particularly grateful to Tony King and Geoffrey Edwards for their detailed comments on the draft manuscript. Hugh Ward and Rob Stones provided invaluable advice on the treatment of economic issues. Gillian Twyman and John Sanders were immensely helpful as non-specialist readers, checking the text for ambiguity and lack of clarity. I should also express my indebtedness to two people I have not met, Bernard Porter and C. J. Bartlett, whose various works were a constant source of information and entertainment while I was writing the book. Finally, thanks to Carole Welge, Carol Snape, Geraldine Shanks and Helen Fitzgerald for their speed and accuracy in producing the final typescript. The responsibility for all errors and misinterpretations is, of course, entirely mine.

Wivenhoe

D.J.S.

Essex 